\title{
Sistem Manajemen Kepala Sekolah dan Wali Asrama dalam Meningkatkan Prestasi Siswa
}

\author{
Muzhari, Sigit Priyo Sembodo. \\ ${ }^{1,2}$ Pascasarjana Institut Pesantren Kh. Abdul Chalim Pacet Mojokerto \\ e-mail: muzh4ri@gmail.com
}

Submitted: 01-01-2020 Revised : 15-02-2020 Accepted: 03-03-2020

\begin{abstract}
The success of headmaster management and boarding school supervisor guidance systems in increasing student achievement were crucial to be researched, especially in boarding school-based schools such as MTs Unggulan Amanatul Ummah Mojokerto which has abundant achievements. The purpose of this study was to describe how the planning, implementation, and evaluation of headmaster management and the boarding school supervisor guidance system in improving student achievement. The study that has been operated as a field study with a descriptive qualitative approach through observation, interview, and documentation methods while data analysis was the Miles and Huberman method included several stages which were data collection, data reduction, data presentation (display), and conclusion or verification. Data validity was performed using data triangulation techniques. The results obtained from the research data indicated that the management of headmaster e. i planning, implementation, and evaluation, has proven to be successful in increasing MTs Unggulan Amanatul Ummah student's achievement. Besides, the planning, implementing, and evaluating of the boarding school guidance system were also effective to improve the achievement of students at MTs Unggulan Amanatul Ummah. However, specifically in the provision of school facilities, it was found that there were still inadequate facilities which were the classes for learning Olympiad. However, it did not affect student achievement due to the brilliance management of the headmaster and guidance systems of boarding school supervisors in improving the achievement of MTs Unggulan Amanatul Ummah students.
\end{abstract}

Keywords: Boarding School Supervisor, Guidance System, Headmaster, Infrastructure, Management.

https:

How to Cite Muzari, M., \& Sembodo, S. P. (2020). Sistem Manajemen Kepala Sekolah dan Wali Asrama dalam Meningkatkan Prestasi Siswa. Munaddhomah: Jurnal Manajemen Pendidikan Islam, 1(2), 88100 ,

\section{PENDAHULUAN}

Pendidikan merupakan suatu proses pembentukan keahlian-keahlian fundamental baik secara intelektual maupun secara emosional yang terarah melalui pengajaran, pelatihan dan penelitian. Pendidikan adalah usaha yang diadakan secara langsung maupun secara tidak langsung untuk membantu manusia dalam mencapai kedewasaan(Abdullah, 2018; Ahmadi \& Uhbiyati, 1991; Ridwan, 2018). Pendidikan dalam pengertian yang lebih luas dapat diartikan sebagai suatu proses pembelajaran kepada peserta didik (manusia) dalam upaya mencerdaskan dan mendewasakan peserta didik tersebut(Susanto, 2007, 2014). Pendidikan adalah kebutuhan pokok bagi setiap manusia, karena manusia saat dilahirkan merupakan makhluk yang belum mengetahui suatu apapun(Ramayulis, 2012, 2013). Sebagaimana firman Allah Ta'ala dalam al-Qur'an sebagai berikut : 


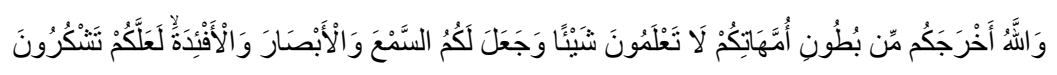

Artinya; "Dan Allah mengeluarkan kamu dari perut ibumu dalam keadaan tidak mengetahui sesuatupun, dan Dia memberi kamu pendengaran, penglihatan dan hati, agar kamu bersyukur"(Al-Qur`an, 2010, p. Surah Nahl. 78).

Pendidikan dalam Islam mempunyai kedudukan yang sangat penting dalam kehidupan sehari-hari karena ilmu pengetahuan baik ilmu agama maupun ilmu pengetahuan umum dapat disebarkan melalui pendidikan. Pada masa kejayaan Islam, ilmu pengetahuan berkembang dengan sangat pesat sehingga menyebabkan kehidupan peradaban masyarakat pada masa itu menjadi semakin pesat (Purnomo \& Umiarso, 2018; Umiarso, 2018). Selain itu, kemajuan di bidang pendidikan juga merupakan indikator dari meningkatnya derajat peradaban suatu bangsa.

Pembelajaran adalah usaha sistematis yang memungkinkan terciptanya pendidikan (Dimyati \& Mudjiono, 1999; SEIFERT, 2007). Proses pembelajaran merupakan aktivitas sadar yang dilakukan untuk menguasai satu atau beberapa kompetensi sebagai milik sendiri (SARONI, 2006). Namun, seiring dengan terjadinya benturan-benturan sepanjang sejarah, saat ini umat Islam seolah menjadi generasi yang hilang. Pendidikan yang berlabelkan keislaman seperti pesantren dan madrasah masih dinilai sebagai pendidikan kelas dua. Kondisi ini menyebabkan banyak cendekiawan muslim menerapkan konsep modernisasi dalam pendidikan Islam, yakni dengan menguasai ilmu agama dan ilmu pengetahuan umum sehingga mampu bersaing dalam kancah internasional. Dalam hal ini, kualitas pendidikan sekolah berbasis pesantren merupakan hal yang menarik untuk diperbincangkan.

Pendidikan agama Islam pada dasarnya adalah inheren dengan pembentukan perilaku sehingga tidak ada pendidikan agama Islam tanpa adanya pembentukan perilaku dan pembentukan budi pekerti luhur (Ghani, 2015). Dengan mengikuti serta melaksanakan kegiatan dan proses pendidikan, manusia akan mampu mencapai tujuan dan cita-cita kehidupannya yaitu kebahagiaan di dunia dan di akhirat.

Pada dasarnya, pendidikan memiliki suatu inti yaitu manajemen, pendidik, peserta didik dan adanya interaksi antara pendidik dan peserta didik. Untuk dapat mencapai maksud dari pendidikan tidaklah mudah. Diperlukan usaha yang sungguh-sungguh, berkesinambungan, dan kerjasama optimal dari berbagai unsur pendidikan. Salah satu diantaranya adalah dengan melaksanakan perencanaan manajemen yang baik, pembelajaran efektif yang dimulai dari perencanaan matang, kontrol, pengawasan, dan evaluasi terus-menerus serta berkelanjutan seperti halnya manajemen pembelajaran di sekolah yang berbasis pondok pesantren(Hafidhuddin, 2003). Dalam pandangan ajaran Islam, segala sesuatu harus dilakukan dengan teliti, cermat dan teratur sehingga serangkaian prosesnya harus dilakukan dengan baik dan teliti. Ini sejalan dengan yang telah diajarkan dalam Islam untuk merencanakan segala kegiatannya sebagaimana Allah Ta'ala berfirman sebagai berikut :

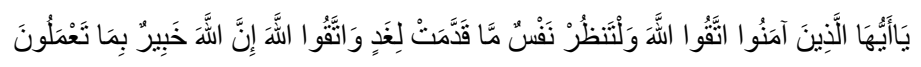

Artinya : "Hai orang-orang yang beriman, bertakwalah kepada Allah dan hendaklah setiap diri memperhatikan apa yang diperbuatnya untuk hari esok (akhirat); dan bertakwalah kepada Allah, sesungguhnya Allah maha mengetahui apa yang kamu kerjakan” (QS. Al-Hasyr:18).

Tenaga kependidikan mempunyai suatu peran yang sangat strategis dalam membentuk pengetahuan, keterampilan, dan karakter peserta didik. Oleh sebab itu, tenaga kependidikan yang profesional akan terus melaksanakan tugasnya secara profesional sehingga menghasilkan siswa yang berprestasi(Rusman, 2011; Zainuddin, 2014). Dalam hal ini, orang-orang yang ada dalam struktur manajemen sekolah terutama kepala sekolah sangat berperan karena kepala sekolah merupakan pemimpin pendidikan yang sangat penting yang berhubungan langsung dengan pelaksanaan program pendidikan di sekolah. 
Dalam hal meningkatkan prestasi siswa, maka suatu lembaga juga harus mempunyai seorang kepala sekolah sebagai manajer yang berkualitas untuk menunjang prestasi siswa melalui program-programnya yang sesuai dengan visi dan misi lembaga tersebut. Ketercapaian tujuan pendidikan sangat bergantung pada kecakapan dan kebijaksanaan kepemimpinan koordinator yakni kepala sekolah yang merupakan salah satu pemimpin pendidikan karena merupakan seorang pejabat profesional dalam organisasi sekolah yang bertugas mengatur semua sumber organisasi dan bekerjasama dengan guru dan wali asrama dalam mendidik siswa untuk belajar di sekolah berbasis pondok pesantren dengan pendidikan formal dan non formal. Dengan kualitas manajerial kepala sekolah tersebut, maka lembaga tersebut akan lebih mudah mengembangkan prestasi siswa sehingga visi dan misi lembaga pendidikan tersebut dapat diraih.

Sekolah yang berbasis pondok pesantren merupakan lembaga sekolah dimana di dalamnya terdapat asrama sebagai tempat tinggal para peserta didik selama masa studi. Pondok pesantren juga memiliki pengasuh yang dikenal sebagai wali asrama yang bertugas membina santri. Kualitas siswa sekolah akan bergantung pada bagaimana manajemen kepala sekolah dan bimbingan wali asrama di pesantren tersebut. Orang-orang yang berada dalam struktur manajemen sekolah mempunyai tanggung jawab dan tugas yang besar dalam meningkatkan prestasi siswa (Ma arif \& Rusydi, 2020; Maarif \& Rofiq, 2018).

Para peserta didik penghuni asrama juga berperan sebagai siswa sekaligus santri yang akan meneladani akhlak orang-orang berilmu di tempat tersebut. Hal ini sebagaimana yang telah dipaparkan oleh Muhaimin dimana istilah "nyantri” mengandung makna 'itba' wa iqtida' akhlaq alulama" (mengikuti dan meneladani akhlaknya ulama, termasuk guru/pendidik yang ahli di bidangnya), sehingga guru/pendidik pun diposisikan dan dikondisikan sebagai ustadz/ustadzah atau kiai/nyai(Kartiko \& Kurniwan, 2018; Muhaimin, 2012). Guru/pendidik yang dimaksudkan di atas adalah pembina asrama beserta dewan guru asrama itu sendiri yang mengampu kegiatan pembelajaran sehari-hari di asrama setelah kegiatan belajar mengajar formal di sekolah selesai.

Asrama merupakan tempat tinggal yang memisahkan interaksi fisik antara peserta didik dengan orang tua. Sehingga dituntut untuk lebih mandiri dalam mewujudkan cita-citanya dan pengembangan diri serta bagaimana peserta didik dituntut untuk bersosialisasi dengan lingkungan yang lebih beragam daripada di kalangan keluarga sendiri. Asrama juga memiliki aturan ataupun tata tertib yang diberlakukan seperti pesantren pada umumnya dan dalam hal meningkatkan prestasi siswa di asrama, diperlukan seorang pendamping dan pembina asrama sebagai pengganti orang tua. Wali asrama mempunyai peran yang tak kalah penting dalam kesuksesan manajer yang mampu mengelola lembaganya dalam upaya meningkatkan prestasi siswa. Keberhasilan dalam mengembangkan prestasi siswa tidak terlepas dari kontribusi manajemen kepala sekolah dalam melaksanakan fungsi dan perannya. Ditambah lagi dengan adanya bimbingan wali asrama yang juga sangat berpengaruh dalam peningkatan prestasi siswa selama masa studinya. Kadang pula, manajerial kepala sekolah dan sistem bimbingan wali asrama biasanya menjadi sorotan dengan mundurnya tingkat prestasi siswa sehingga menurunnya kualitas kelulusan siswa tersebut yang terkadang sangat jauh berbeda dari yang seharusnya dan tampak tidak rasional. Untuk itu, maka kepala sekolah dan wali-wali asrama dituntut mampu dan siap dalam menjalankan tugasnya masing-masing agar bisa menjalankan visi dan misi sekolah yang berbasis pondok pesantren dengan tujuan untuk melahirkan siswa berprestasi dan berakhlakul karimah. Hal ini dilakukan demi menonjolkan kemuliaan Islam dan kaum muslimin di mata dunia serta demi mengangkat derajat kemuliaan bangsa Indonesia untuk keberhasilan cita-cita kemerdekaan dengan adanya peningkatan prestasi siswa di lembaga tersebut.

Peningkatan prestasi siswa sangat ditentukan oleh bagaimana kepala sekolah dalam menjalankan tugas dan fungsinya yang juga didukung oleh sarana-prasarana yang memadai dan sistem bimbingan wali asrama dalam mengawasi siswa diluar jam pelajaran sekolah untuk membentuk karakter santri yang baik dan disiplin demi melahirkan siswa-siswi berprestasi. Dalam rangka peningkatan prestasi siswa, seorang kepala sekolah sebagai manajer harus mampu 
mengorganisasikan seluruh komponen sekolah termasuk wali asrama yang bertugas membimbing siswa. Kepala sekolah juga harus memahami kebutuhan sekolah yang ia pimpin sehingga kompetensi wali asrama tidak hanya berhenti pada kompetensi yang ia miliki sebelumnya, melainkan kian bertambah dan berkembang dengan baik sehingga profesionalisme wali asrama akan terwujud.

Salah satu contoh kasus yang dijadikan bahan penelitian adalah lembaga pendidikan Madrasah Tsanawiyah Unggulan Amanatul Ummah Mojokerto yang terletak di Kecamatan Pacet, Desa Kembang Belor yang berbasis pendidikan pondok pesantren. Di asrama MTs Unggulan Amanatul Ummah ini juga memiliki berbagai program yang menjadi acuan dalam meningkatkan prestasi dan sebagainya. Kegiatan atau program ini dilaksanakan di asrama, gedung sekolah atau masjid setelah jam belajar-mengajar di sekolah telah usai.

MTs Unggulan Amanatul Ummah merupakan sekolah swasta yang berada dibawah naungan seorang kyai pondok pesantren. Namun, dalam pembelajarannya menggunakan kurikulum dari Kementerian Agama dan Kementerian Pendidikan Nasional. MTs Unggulan Amanatul Ummah selalu diminati orang tua siswa/peserta didik karena selain pembelajarannya yang mengedepankan mata pelajaran agama dan umum, madrasah ini juga memiliki deretan prestasi siswa yang berlimpah sehingga seringkali melahirkan lulusan-lulusan terbaik. Hal ini dibuktikan dengan seringnya sekolah tersebut mendapatkan gelar juara setiap kali diadakan perlombaan baik di tingkat kecamatan, kabupaten, provinsi bahkan di tingkat Nasional.

\section{METODE PENELITIAN}

Penelitian ini menggunakan pendekatan kualitatif deskriptif yang dilakukan melalui gambaran secara sistematis, faktual dan akurat mengenai fakta-fakta di lapangan dimana terdapat fenomena-fenomena tertentu yang harus diteliti. Penelitian ini merupakan penelitian lapangan (field research) dengan jenis penelitian kualitatif. Pada penelitian kualitatif, analisis yang dilakukan lebih menekankan pada analisis terhadap proses penyimpulan data secara deduktif dan secara induktif serta analisis dalam bentuk dinamika hubungan antara fenomena yang harus diamati dengan menggunakan logika ilmiah sedangkan metode yang digunakan adalah metode studi kasus dengan menggunakan metode pengumpulan data yaitu metode observasi, dokumentasi. Penelitian ini dilakukan dengan cara menelusuri kejadian berdasarkan metode studi kasus dimana dengan cara mencari secara mendalam baik program, kejadian, aktivitas, proses, maupun satu individu atau lebih. Dalam metode ini, kasus yang diamati melibatkan waktu dan aktivitas serta peneliti yang mengumpulkan data dalam suatu periode waktu tertentu. Dalam hal ini, penelitian dilakukan untuk meninjau bagaimana mendeskripsikan manajemen kepala sekolah dan sistem bimbingan wali asrama dalam meningkatkan prestasi siswa di MTs Unggulan Amanatul Ummah Pacet Mojokerto.

Adapun sumber data dari penelitian dapat dibagi menjadi dua yaitu sumber data primer dan sumber data sekunder. Data primer adalah data yang harus diambil secara langsung tanpa perantara dari sumbernya dimana subjek sebagai sumber informasi yang dicari adalah melalui wawancara mendalam yang dilakukan terhadap kepala sekolah sebagai koordinator sekolah/madrasah, waka kesiswaan, waka kurikulum, pembina olimpiade, ketua wali asrama, wali asrama dan guru-guru. Selain itu, data primer juga dapat ditemukan dari pengamatan (observasi) dan dokumentasi. Data sekunder adalah data yang harus diambil secara tidak langsung dari sumbernya yaitu sumber data yang berkaitan dengan permasalahan dibahas seperti data dari bukubuku, dokumen-dokumen, jurnal-jurnal, artikel-artikel, tesis, skripsi, atau catatan-catatan dan data lainnya. Teknik analisis data yang digunakan oleh peneliti ialah teknik analisis data model interaktif milik (Miles et al., 2014) yang meliputi: tahap pengumpulan data, reduksi data, display/penyajian data, dan kesimpulan/verifikasi”

Pada penelitian ini, peneliti menggunakan triangulasi data sebagai pemeriksaan data yang dilakukan melalui sumber lainnya. Dalam pelaksanaannya, peneliti harus melakukan pengecekan 
data yang berasal dari wawancara koordinator sekolah, waka kesiswaan, waka kurikulum, pembina olimpiade, ketua wali asrama, wali asrama, guru-guru dan para siswa yang dimintai kesediaannya untuk memberikan keterangan yang diperlukan.

Berdasarkan data wawancara tersebut, peneliti kemudian memeriksa data-data dari hasil pengamatan yang telah selesai dilakukan selama masa penelitian. Selanjutnya, metode ini digunakan untuk mengeksplorasi kata-kata secara faktual untuk mengetahui bagaimana manajemen kepala sekolah dan system bimbingan wali asrama dalam meningkatkan prestasi siswa/santri di MTs Unggulan Amanatul Ummah Pacet Mojokerto dengan mengacu kepada teori-teori yang relevan

\section{HASIL DAN PEMBAHASAN}

Berdasarkan hasil pembahasan mengenai Hubungan Motivasi Kerja dan Disiplin Kerja dengan Kinerja Pegawai di Dinas Pendidikan Kabupaten Mojokerto, maka diperoleh kesimpulan sebagai berikut:

\section{Perencanaan Manajemen Kepala Sekolah}

Secara garis besar, jika dikaitkan dengan fungsi manajemen yaitu perencanaan (planning), pengorganisasian (organizing), penggerakan (directing) dan pengawasan (controlling) sebagaimana yang telah diungkapkan oleh George R. Terry dalam (SUTOPO, 1993), maka pengembangan akademis siswa sebagai suatu manajemen kepala sekolah di MTs Amanatul Ummah ini menjadi suatu bukti nyata bahwa sistem manajemen kepala sekolah telah melengkapi keempat fungsi manajemen tersebut. Hal ini dikarenakan dalam proses pengembangan akademis siswa, diperlukan semua fungsi manajemen yang mesti terkandung di dalamnya. Sebagai contoh, dalam proses persiapan pengembangan akademis yang digagas kepala sekolah, diperlukan rencana yang baik, kemudian dilanjutkan dengan sistem organisasi yang baik antara kepala sekolah dengan guru-guru dan staf-staf terkait baik secara langsung maupun tidak langsung dalam upaya pengembangan keterampilan akademis siswa.

Tahap awal dari suatu manajemen yang harus dikerjakan adalah perencanaan (planning) dimana untuk memulai suatu pelaksanaan kegiatan dengan baik dan benar, rencana yang terstruktur manjadi sangat penting. Berdasarkan hasil analisis peneliti, dalam proses perencanaan, kepala sekolah terlebih dahulu menyusun rencana dengan mempelajari kebijakan yayasan Pondok Pesantren Amanatul Ummah yaitu dengan melakukan perencanaan seleksi masuk yang ketat melalui PPDB (Penerimaan Peserta Didik Baru), melakukan perencanaan untuk penerimaan tenaga pengajar yang sangat selektif dan melakukan perencanaan kegiatan belajar-mengajar (KBM) yang terarah dalam MGMP (Musyawarah Guru Mata Pelajaran). Semua perencanaan tersebut disusun melalui rapat dengan seluruh civitas yang ada di MTs Unggulan Amanatul Ummah sehingga terbentuk serangkaian rencana tahunan yang baik untuk diterapkan dalam kegiatan pembelajaran siswa di sekolah.

Hal terpenting yang harus dilaksanakan adalah membuat target yang terukur dalam setiap tahapan.

Ketika ditinjau dari analisis yang telah dikemukakan sebelumnya, maka kemampuan manajemen kepala sekolah dalam menyusun perencanaan dapat dikaitkan dengan pendapat Robert L. Katz yang tertulis dalam (Stoner et al., 1996) yaitu "A teacher and business executive, bas identified three basic kinds of skills : technical, buman and conceptual." Yang bermaksud : Ada tiga macam kemampuan yang harus dikuasai oleh manajer yaitu teknis, manusiawi dan konseptual.

Kemampuan teknis adalah kemampuan manusia khususnya seorang manajer dalam sebuah organisasi untuk menggunakan suatu prosedur, teknik dan pengetahuan mengenai bidang tertentu. Maka dapat dipastikan berdasarkan beberapa paparan hasil wawancara sebelumnya bahwa kepala sekolah sebagai leader terbukti memiliki kemampuan teknis yang baik khususnya dalam hal-hal yang berkaitan dengan peningkatan prestasi siswa. Selain itu, beliau juga memiliki kemampuan 
manusiawi yang juga sangat baik karena pada dasarnya, kemampuan ini adalah suatu keahlian seorang manajer dalam bekerjasama, memahami dan memotivasi orang lain sebagai individu atau dalam kelompok. Indikator ini juga terbukti dikuasai dengan sempurna oleh kepala sekolah sebagai seorang koordinator di MTs Amanatul Ummah.

Kepala sekolah juga mempunyai kemampuan konseptual yang sesuai dengan teori yang telah disampaikan oleh Robert L. Katz dimana perlunya koordinasi dan integrasi semua kepentingan dan aktivitas organisasi. Oleh karenanya, kepala sekolah MTs Unggulan Amanatul Ummah dipercaya memiliki penguasaan manajerial yang sangat baik berdasarkan telaah peneliti yang telah dilaksanakan.

\section{Perencanaan Sistem Bimbingan Wali Asrama}

Dalam pembelajaran sekolah berbasis kepesantrenan seperti di MTs Unggulan Amanatul Ummah, peran wali asrama dalam meningkatkan prestasi siswa juga bersifat sangat esensial disamping adanya peran kepala sekolah sebagai penanggungjawab utama di sekolah. Ini dikarenakan wali asrama merupakan kunci utama pendidikan dan pembimbingan siswa setelah siswa selesai melalui tahapan pembelajaran di kelas (sekolah) yang kemudian dilanjutkan dengan melaksanakan serangkaian kegiatan pendidikan keagamaan di pondok pesantren (asrama). Dengan adanya wali asrama selama siswa melakukan kegiatan pengajian dan pembelajaran keagamaan tesebut, maka segala kegiatan siswa/santri akan lebih terawasi dengan baik. Selain itu, dorongan motivasi dari wali asrama akan sangat bermanfaat dalam kehidupan di pondok pesantren untuk terus meningkatkan prestasi dan meng-upgrade diri siswa sehingga mampu menjadi pribadi berkarakter terpuji.

Berdasarkan analisis yang telah dilakukan, dapat diidentifikasi dengan pasti bahwa perencanaan yang dilakukan oleh ketua wali asrama dan seluruh wali asrama yang ada di MTs Unggulan Amanatul Ummah Mojokerto dilakukan dalam rapat dimana wali asrama bersama dengan ketua wali asrama membentuk serangkaian perencanaan yang disusun di awal tahun untuk diterapkan pada anak-anak peserta didik. Selain itu, rapat mingguan juga dilakukan jika ada perubahan atau penambahan perencanaan tertentu. Sistem perencanaan semacam ini terbukti berhasil tidak hanya dalam pengaturan dan pengawasan kepribadian siswa, namun juga dalam meningkatkan prestasi siswa.

Hal ini sesuai dengan yang telah digambarkan oleh Djamaluddin dimana dibutuhkan suatu perencanaan asrama yang matang dalam upaya mengoptimalkan sistem pendidikan di pesantren melalui pengurusan asrama. Perencanaan yang dilakukan disusun oleh para pengurus pesantren, pengurus asrama, ketua-ketua kamar dan anggota kamar. Pada akhirnya, perencanaan tersebut harus diketahui dan disetujui oleh pengurus-pengurus yang lain, para guru dan kyai. Dalam tahapan perencanaan ini, semua elemen pengurus hadir dan menyusun kegiatan secara bersamasama untuk mendukung keberhasilan pembelajaran santri. Rapat kerja asrama akan menghasilkan suatu catatan berupa draf kegiatan asrama untuk jangka waktu setahun dimana dalam draf tersebut tercantum kegiatan-kegiatanharian, bulanan, semester, dan bahkan tahunan. Perincian kegiatankegiatan dalam draf tersebut disusun berdasarkan perencanaan waktu dan biaya yang dibutuhkan (Perawironegoro, 2019).

\section{Pelaksanaan Manajemen Kepala Sekolah}

Selain yang telah dijelaskan sebelumnya tentang keberhasilan manajemen kepala sekolah, komitmen dan motivasi yang layak diapresiasi ditunjukkan oleh kepala sekolah dalam pengaturan setiap tugas yang diamanahkan baik kepada dirinya sendiri sebagai pemimpin sekolah maupun kepada guru-guru dan staf-staf lainnya. Selain itu, koordinasi dan kerjasama yang baik antara kepala sekolah dengan semua stafnya dan antara sesama staf di MTs Amanatul Ummah dalam menjalankan semua kegiatan pembelajaran demi meningkatkan prestasi siswa sehingga tercipta kekompakan antara semua civitas akademik sekolah. Upaya lainnya dalam rangka pelaksanaan 
manajemen kepala sekolah adalah menerapkan kedisiplinan dan menanamkan jiwa kompetitif pada siswa MTs Amanatul Ummah (umumnya dengan pengadaan try out rutin dan olimpiade).

Berdasarkan upaya-upaya pelaksanaan manajemen yang telah disebutkan, maka penulis menilai bahwa hal-hal tersebut menjadi penunjang keberhasilan manajemen kepala sekolah dalam meningkatkan prestasi siswa di MTs Unggulan Amanatul Ummah Mojokerto. Jika ditelusuri lebih lanjut pada hasil penelitian oleh Hendyat (SUTOPO, 1993)bahwa perlunya pengarahan, dorongan, koordinasi, dan kepemimpinan yang efektif untuk mendapatkan keterpaduan kerja organisasi, maka dapat dipastikan bahwa kepala sekolah telah melaksanakan manajemen dengan sangat baik.

Menurut studi yang telah dikaji oleh Muh (Fitrah, 2017) dalam sebuah publikasi ilmiah, pentingnya peranan kepala sekolah dalam rangka meningkatkan mutu pendidikan didasari pada keberhasilan yang tampak pada mutu pendidikan itu sendiri. Secara garis besar, kepala sekolah memiliki ruang lingkup tugas yang dapat diklasifikasikan ke dalam dua aspek pokok, yaitu pekerjaan di bidang administrasi sekolah dan pekerjaan yang berkenaan dengan pembinaan profesional kependidikan. Selain itu, ramai di kalangan guru yang memiliki persepsi bahwa keberhasilan kepemimpinan kepala sekolah memiliki landasan utama berupa kemampuannya dalam memimpin. Mereka berpendapat bahwa stabilitas dan emosi serta rasa percaya diri merupakan kunci bagi kelancaran kerja kepala sekolah dalam memimpin. Secara psikologis, ini merupakan landasan utama dimana kepala sekolah perlu memperlakukan stafnya secara adil, memberikan keteladanan dalam bersikap, bertingkah laku dan melaksanakan tugas.

Dalam konteks ini, kepala sekolah dituntut untuk menampilkan kemampuannya membina kerjasama dengan seluruh personal dalam iklim kerja terbuka yang bersifat kemitraan serta meningkatkan partisipasi aktif dari orang tua murid. Semua hal yang diuraikan oleh Muh Fitrah tersebut telah berhasil dilakukan oleh kepala sekolah MTs Unggulan Amanatul Ummah dibuktikan dengan kualtas sekolah yang sangat terpercaya melalui prestasi-prestasi yang dimiliki siswasiswanya.

Sebagai contoh, adanya kelas CI (Cerdas Istimewa) dan Excellent yang diterapkan dengan masa studi yang relatif singkat dan target pencapaian prestasi akademis yang sangat menggembirakan. Pencapaian juara-juara pada kegiatan olimpiade dan peraihan peringkat 1 sampai 20 besar untuk penyelenggaraan try out se-Jawa Timur juga menjadi suatu indikator kecemerlangan siswa yang dihasilkan dari pelaksanaan sistem manajemen kepala sekolah yang baik.

Menurut Umi (RASMI, 2019), kepala madrasah dalam kepemimpinannya mesti melakukan sesuatu untuk semua unsur yang menduduki posisi sebagai bawahannya. Ini dikarenakan secara hakikat, seorang pemimpin tidak selayaknya meminta dilayani oleh orang-orang yang ada di bawah kepemimpinannya sebaliknya, ia harus memberi pelayanan bagi pihak yang dipimpinnya. Seorang kepala sekolah dapat menciptakan hubungan yang harmonis antara dirinya dengan bawahannya ataupun dengan atasannya melalui gaya kepemimpinan yang diterapkansehingga pelaksanaanpendidikan berlangsung sesuai dengan visi, misidan tujuan sekolah.

Hal ini dapat dikonfirmasi dari pemaparan rinci yang telah dilakukan dalam paparan data penelitian dimana terdapat banyak usaha yang telah dilakukan kepala sekolah demi mencapai keberhasilan peningkatan prestasi siswa sehingga MTs Unggulan Amanatul Ummah dipercayai sebagai Madrasah Tsanawiyah yang bermutu. Kepala sekolah telah melakukan sangat banyak upaya seperti memberikan motivasi baik kepada pengajar maupun siswa yang berprestasi, menjalin kekompakan antar sesama civitas akademik sekolah, memberikan reward (penghargaan) kepada guru dan siswa berprestasi serta menerapkan budaya disiplin dan kompetitif pada siswa.

Terdapat beberapa faktor pendukung terlaksananya upaya peningkatan prestasi siswa yang dapat digambarkan oleh peneliti berdasarkan hasil penelitian yang telah dilaksanakan. Adapun beberapa faktor tersebut adalah olimpiade (ajang mengasah prestasi siswa) yang diikutsertakan oleh siswa-siswa setelah melalui seleksi untuk menentukan kualifikasi siswa. Selain itu, faktor siswa 
(peserta didik) sebagai individu juga dapat menentukan keberhasilannya dalam meraih dan meningkatkan prestasi (terdapat 2 faktor yang mempengaruhi pribadi siswa yaitu faktor genotip dan fenotip) serta faktor guru (tenaga pengajar) juga sangat berefek terhadap kegemilangan sekolah khususnya dalam meningkatkan prestasi siswa dimana kualitas guru mencerminkan kualitas murid yang dididik sehingga guru yang baik dalam mengajarkan siswa akan mempengaruhi kesuksesan siswa itu sendiri.

Jika ditelusuri lebih jauh melalui hasil penelitian di MTs Unggulan Amanatul Ummah ini, terdapat beberapa faktor lainnya yang diupayakan oleh semua komponen sekolah baik oleh kepala sekolah, para guru dan bahkan oleh staf-staf sekolah lainnya dalam mendukung raihan keberhasilan siswa yaitu mengevaluasi bidang siswa berdasarkan karakter (minat dan bakat), memberikan motivasi dan sarana-prasarana sekolah yang memadai.

Namun, setelah peneliti mengobservasi secara langsung, melakukan wawancara dan membuat dokumentasi, peneliti mendapati adanya keterbatasan khususnya dalam penyediaan sarana sekolah yaituketiadaan kelas yang diperuntukkan untuk kegiatan pembelajaran olimpiade. Dalam hal ini, jika dihubungkan dengan kecemerlangan siswa dalam meraih prestasi, hal ini jelas bertolak belakang dengan teori sebagaimana yang dikatakan oleh (Jamal Ma`mur, 2012; Jasmani \& Syaiful, 2013) dalam bukunya dimana jika sarana dan prasarana minim, maka semangat siswa dalam belajar akan melemah dan akan sulit mendapatkan prestasi .

Akan tetapi, berbeda halnya dengan teori yang dikemukakan tersebut, kekurangan sarana dan prasarana sekolah tidak berimbas secara negatif terhadap semangat para murid dan keberhasilan siswa MTs Unggulan Amanatul Ummah khususnya dalam peningkatan prestasinya. Hal ini dikarenakan adanya komitmen dan motivasi yang kuat dari semua pihak, koordinasi dan kerjasama yang baik antara semua civitas akademik sekolah serta upaya menerapkan kedisiplinan dan jiwa kompetitif pada siswa sehingga prestasi yang diraih siswa justru tetap mengalami peningkatan.

\section{Pelaksanaan Sistem Bimbingan Wali Asrama}

Selain melakukan perencanaan dengan baik yang dipersiapkan sebelumnya, wali asrama juga diharuskan melaksanakan tugasnya dengan baik. Secara garis besar, tugas-tugas yang diberikan kepada wali asrama adalah membimbing dan mengarahkan siswa/santri MTs Unggulan Amanatul Ummah akan segala hal yang melibatkan kebutuhan siswa seperti pendidikan karakter (adab) dan pembelajaran akademis baik pelajaran sekolah maupun pelajaran keagamaan di pesantren. Tugas wali asrama lainnya adalah mengawasi setiap tingkah laku siswa selama berada di lingkungan asrama sehingga sikap dan sifat terpuji yang tertanam dalam diri setiap siswa serta ketercapaian prestasi pada setiap pribadi siswa lebih mudah terealisasi. Wali asrama selayaknya berperan sebagai motivator para siswa/santri sehingga jika ada pelangaran-pelanggaran atau ketidakseriusan dalam belajar yang dilakukan peserta didik di asrama, maka wali asrama yang berkewajiban memberikan motivasi agar hal tersebut segera dikoreksi menjadi lebih baik dari sebelumnya.

Hal ini dapat dipastikan sebagai suatu kenyataan yang terjadi di asrama Pondok Pesantren Amanatul Ummah selama peneliti mengobservasi secara langsung pada setiap kegiatan dan rutinitas yang dijalankan. Selain itu, data-data wawancara yang telah dikumpulkan dan dianalisis juga menunjukan hasil yang sangat positif khususnya dalam pelaksanaan bimbingan wali asrama. Sehubungan dengan hal tersebut, Djamaluddin dalam sebuah artikel ilmiahnya juga menerangkan bahwa pengurus asrama diharapkan mampu memberikan stimulan kepada sesama pengurus dan santri dalam rangka memotivasi agar dapat bekerjasama mengelola asrama supaya tercipta keamanan dan kenyamanan sesuai yang diharapkan.

Dalam memberikan motivasi, dibutuhkan kemampuan khusus bagi pengurus dimana seorang pengurus harus mampu mendorong, menginspirasi dan memberikan semangat kepada 
orang di sekitarnya dengan penawaran realistis. Seorang pengurus juga diharapkan memiliki pengalaman dan pengetahuan yang luas dalam bidang keahliannya.

Suatu proses kerjasama dalam segala bentuk kegiatan mulai dari perencanaan, pengorganisasian, pengarahan, dan bahkan kegiatan pengendalian dari semua sumber daya (komponen organisasi atau institusi) sangat diperlukan untuk mencapai tujuan pendidikan. Penting dilakukan implementasi dan penyusunan yang memiliki arah dan tujuan yang konkrit dari semua fungsi manajemen yang meliputi perencanaan, pengorganisasian, pengarahan, dan pengendalian. Dalam mengelola asrama di pesantren, pelaksanaan fungsi-fungsi manajemen tersebut akan sangat membantu pengurus asrama (wali asrama) dalam tahap pengendalian dan peningkatan potensi organisasi pesantren.

Untuk memastikan terlaksananya program-program yang direncanakan dan diorganisasikan, maka perlu dilakukan upaya penggerakan asrama. Terdapat beberapa program yang penting untuk diterapkan dalam kehidupan berasrama di pesantren yaitu menjaga keamanan, memastikan ketertiban hidup bersama, menjaga kebersihan asrama, membudayakan kedisiplinan dalam mengikuti kegiatan pesantren, meningkatkan keterampilan berbahasa dan menghidupkan kebersamaan.

Dalam istilah manajemen, penggerakan (actuating) perlu dilakukan untuk menjalankan berbagai program tersebut.Dalam kepengurusannya, wali asrama (pengurus asrama) diberi kepercayaan dan sangat diharapkan mampu menjadi sosok pemimpin dan manajer di asrama. Jika dihubungkan dengan fungsi kepemimpinan, maka para pengurus asrama (wali asrama) mesti memiliki beberapa kemampuan berikut, yaitu :

1) Menjadi teladan bagi warga asrama 2) Mengambil beberapa keputusan yang berhubungan dengan dinamika kehidupan asrama. 3) Mengadakan komunikasi dengan pengurus yang lain. 4) Memberikan motivasi kepada para pengurus yang lain dan para santri. 5) Memberikan evaluasi terhadap sesama pengurus. 6) Menerima saran dan masukan dari para pengurus dan santri.

Selain itu, dalam sebuah kehidupan berasrama, komunikasi yang efektif juga sangat dibutuhkan untuk menggerakkan semua pengurus (wali asrama) dan santri untuk dapat saling bekerjasama menciptakan asrama yang kondusif. Komunikasi yang dimaksud adalah penyampaian ide-ide dan gagasan yang baik dan benar tergantung pada cara hidup bersama di asrama dalam ruang lingkup pesantren.Penyampaian gagasan oleh pengurus asrama dapat dilakukan secara langsung atau tidak langsung.

Penyampaian secara langsung dilakukan dalam forum-forum kelompok seperti pada kegiatan pengarahan dalam agenda-agenda rapat resmi atau melalui pendekatan tehadap individu seperti dengan cara menyampaikan pada santri yang bersangkutan tentang hal-hal penting menyangkut kehidupan di asrama. Sementara itu, penyampaian gagasan secara tidak langsung dapat dilakukan melalui media-media yang ada di asrama berupa nasehat, kata hikmah dan bahkan simbol-simbol yang tidak bertentangan dengan nilai-nilai dan tradisi pesantren.

\section{Evaluasi Manajemen Kepala Sekolah}

Setelah perencanaan dan pelaksanaan manajemen selesai dilakukan dalam sebuah organisasi dimana dalam hal ini adalah MTs Unggulan Amanatul Ummah, maka tahap akhir yang menjadi keharusan ialah evaluasi. Tahapan pelaksanaan evaluasi yang dilakukan menjadi salah satu proses penting dalam sistem manajemen kepala sekolah dengan tujuan untuk mempelajari bagaimana keberlangsungan progres pembelajaran siswa yang sebelumnya dilalui. Pembelajaran yang telah dilewati oleh siswa harus dinilai kembali keberhasilannya oleh kepala sekolah sebagai pemimpin sekolah.

Dalam dunia pendidikan, evaluasi yang dilakukan ditujukan untuk mengidentifikasi hasil dari kegiatan belajar-mengajar dalam periode waktu tertentu sehingga hasil yang diperoleh dapat 
diukur kualitasnya dengan baik. Tahap evaluasi ini dilakukan terhadap progres peningkatan prestasi siswa (perkembangan akademisnya), progres guru-guru yang mengajar dan bahkan progres dari pembimbingan waka kesiswaan, waka kurikulum, dan semua civitas akademik MTs Unggulan Amanatul Ummah Mojokerto. Menurut (Maulida, 2018), evaluasi merupakan suatu langkah refleksi yang bertujuan untuk melihat kembali hasil yang telah diperoleh sebelumnya. Tujuan lainnya adalah sebagai perbaikan berkelanjutan untuk meningkatkan prestasi peserta didik dan mutu pendidikan.

Evaluasi manajemen kepala sekolah dapat diamati dari mutu pendidikan yang berhasil diperoleh lembaga yang dipimpinnya. Secara keseluruhan, evaluasi yang merupakan penaksiran keberhasilan manajemen kepala sekolah khususnya dalam meningkatkan prestasi siswa dapat dilihat dari banyaknya deretan prestasi yang telah diraih sebelumnya. Selain itu, harumnya nama baik MTs Unggulan Amanatul Ummah di mata masyarakat secara umum juga menjadi indikasi kegemilangan pencapaian kepala sekolah dalam mengatur sekolah sehingga menjadi suatu lembaga pendidikan yang bermutu.

Perolehan piagam-piagam penghargaan yang telah dimiliki MTs Unggulan Amanatul Ummah salah satunya sebagai sekolah paling inspiratif di Indonesia pada tahun 2019 juga menjadi bukti nyata bahwa kepala sekolah berhasil membawa kebaikan dalam mengkoordinasikan kepemimpinannya dengan semua pihak yang terlibat. Namun, segala kesuksesan dalam manajemen kepala sekolah tidak pernah terlepas dari kinerja para guru yang bersungguh-sungguh, Waka kesiswaan, Waka kuruikulum, Pembina olimpiade, fungsionaris dan seluruh staf yang bersedia bekerjasama dengan baik setiap saat.

Pelaksanaan evaluasi yang dijalankan juga dimaksudkan sebagaimana pendapat Hendyat Sutopo dimana setiap pelaksanaan kegiatan dalam suatu sistem manajemen yang dijalankan harus dikendalikan, dimonitor dan dievaluasi keefektifan dan keefisienannya. Hasil yang diperoleh dari rangkaian proses tersebut kemudian menjadi feedback yang sangat berguna dalam usaha penyempurnaan dan peningkatan perencanaan, pengorganisasian, dan pelaksanaan kegiatan berikutnya.

Oleh karena itu, dapat diyakini bahwa kepala sekolah MTs Amanatul Ummah telah menjalankan fungsi manajemen yang berkait erat dengan sistem manajemennya yaitu pengawasan (controlling) dimana pada setiap proses pengembangan akademis yang dilaksanakan oleh kepala sekolah, pengawasan yang hati-hati sangat dibutuhkan demi tercapainya keberhasilan yaitu berkembangnya potensi akademik dalam rangka mengupayakan peningkatan prestasi siswa.

\section{Evaluasi Sistem Bimbingan Wali Asrama}

Tahap terakhir dalam suatu manajemen adalah evaluasi dimana wali asrama dalam menjalankan tugasnya juga diharuskan untuk melakukan evaluasi terhadap perkembangan anakanak peserta didik yang berada di bawah tanggungjawabnya. Hal yang sama juga dikemukakan oleh Djamaluddin dimana setelah selesai melakukan proses perencanaan, pengorganisasian dan penggerakan, maka fungsi manajemen akhir yang harus digarisbawahi adalah melakukan pengawasan melalui evaluasi. Farida (Galela, 2012)menyatakan bahwa pada dasarnya, evaluasi harus dilakukan dengan tujuan untuk mengetahui bagaimana prestasi atau hasil belajar setiap peserta didik/santri pada semua pembelajaran yang dilakukan dimanapun dan kapanpun, begitu juga halnya dengan pendidikan di asrama sebagaimana yang telah dikaji. Walau demikian, terkadang cara atau teknik yang digunakan berbeda-beda.

Dengan adanya evaluasi, maka dapat diketahui segala hal yang mungkin masih harus dikoreksi dan diregulasi dengan kebijakan-kebijakan baru yang lebih efektif dalam rangka meningkatkan kualitas pendidikan dan pembelajaran siswa/santri dimana dalam hal ini, siswa yang dimaksud adalah siswa MTs Unggulan Amanatul Ummah Mojokerto. Sejalan dengan hal tersebut, Djamaluddin menyatakan bahwa keberadaan asrama menjadi kebutuhan seiring dengan 
didirikannya lembaga pendidikan berbasis pondok pesantren. Umumnya, asrama masih belum dapat dikelola melalui pendekatan manajerial dengan menelusuri aspek perencanaan, pengorganisasian, pengarahan, dan pengawasan yang baik.

Evaluasi yang dilakukan oleh wali asrama meliputi pengawasan dan penilaian perkembangan siswa yang dibahas dalam rapat mingguan antara ketua wali asrama dengan seluruh wali asrama yang ditugaskan sehingga dapat diketahui segala perkembangan dan kekurangan yang dihasilkan dari perencanaan dan pelaksanaan bimbingan yang telah dilaksanakan. Selain itu, evaluasi juga dapat dilakukan dengan melihat perkembangan siswa melalui prestasi yang diperoleh.

Menurut (Marzan, 2020)evaluasi dalam Manajemen Pendidikan Islam memiliki 2 batasan yaitu : 1) Evaluasi adalah suatu perbandingan antara proses (kegiatan) dalam rangka menentukan kemajuan pendidikan dengan tujuan yang telah dipastikan sebelumnya. 2) Evaluasi merupakan suatu tahapan dalam upaya memperoleh informasi dalam bentuk umpan balik (feedback) setelah selesai menjalankan serangkaian kegiatan.

Berdasarkan kedua batasan yang digambarkan oleh Marzan tersebut, maka dapat disimpulkan bahwa wali asrama yang berperan sebagai pembimbing para siswa telah berhasil melaksanakan setiap batasan tersebut melalui rapat rutin mingguan sebagaimana yang telah dijelaskan sebelumnya

\section{KESIMPULAN}

Perencanaan manajemen kepala sekolah dalam meningkatkan prestasi siswa dilakukan dengan melaksanakan pengembangan akademis siswa melalui penyusunan rencana berdasarkan kebijakan Yayasan Pondok Pesantren Amanatul Ummah. Adapun tahapan-tahapan pengembangan akademis siswa adalah : a) perencanaan seleksi masuk siswa yang ketat melalui Penerimaan Peserta Didik Baru (PPDB); b) perencanaan penerimaan tenaga pengajar yang selektif; dan c) perencanaan kegiatan belajar-mengajar (KBM) melalui MGMP (Musyawarah Guru Mata Pelajaran). Perencanaan manajemen kepala sekolah terbukti berhasil dalam meningkatkan prestasi siswa MTs Unggulan Amanatul Ummah Mojokerto.

Perencanaan sistem bimbingan wali asrama dalam meningkatkan prestasi siswa dilakukan dengan dua upaya yaitu : a) menyusun perencanaan kegiatan siswa setiap tahun melalui rapat-rapat wali asrama di awal tahun; dan b) melakukan perubahan atau penambahan rencana melalui rapat mingguan. Perencanaan sistem bimbingan wali asrama yang telah disusun juga terbukti berhasil dalam meningkatkan prestasi siswa selama berada di asrama Pondok Pesantren Amanatul Ummah Mojokerto.

Pelaksanaan manajemen kepala sekolah dalam meningkatkan prestasi siswa dilakukan dengan beberapa upaya yaitu : a) komitmen dan motivasi yang kuat dari kepala sekolah MTs Unggulan Amanatul Ummah; b) koordinasi dan kerjasama yang baik antara semua civitas akademik sekolah MTs Unggulan Amanatul Ummah baik dengan kepala sekolah selaku pemimpin maupun dengan sesama pengajar dan staf-staf lain; dan c) penerapan kedisiplinan dan jiwa kompetitif pada siswa MTs Unggulan Amanatul Ummah. Pelaksanaan manajemen kepala sekolah yang telah diterapkan terbukti dapat meningkatkan prestasi siswa MTs Unggulan Amanatul Ummah Mojokerto.

Pelaksanaan sistem bimbingan wali asrama dalam meningkatkan prestasi siswa dilakukan berdasarkan tugas dan kewajiban wali asrama yaitu: a) membimbing dan mengarahkan siswa/santri MTs Unggulan Amanatul Ummah pada pembelajaran adab dan akhlak (pembentukan karakter) serta pembimbingan untuk pembelajaran sekolah dan keagamaan; dan b) mengawasi segala tingkah laku siswa dan memberikan dorongan motivasi jika ditemukan pelanggaran-pelanggaran atau ketidakseriusan dalam proses belajar siswa/santri dengan tujuan agar tercipta pribadi-pribadi berakhlakul karimah dan berprestasi. Pelaksanaan sistem bimbingan wali asrama yang telah 
diaplikasikan terbukti efektif meningkatkan prestasi siswa/santri khususnya di asrama Pondok Pesantren Amanatul Ummah Mojokerto.

Evaluasi manajemen kepala sekolah dalam meningkatkan prestasi siswa dilakukan terhadap : a) progres dari peningkatan prestasi siswa (bagaimana perkembangan akademis siswa melalui hasil pencapaian yang telah diperoleh); dan b) penilaian perkembangan pendidikan dan keterampilan siswa oleh guru-guru, waka kesiswaan, waka kurikulum dan semua civitas akademik MTs Unggulan Amanatul Ummah. Evaluasi dilakukan dengan melihat penambahan dan perkembangan deretan prestasi yang berhasil diraih siswa serta dengan menilai keberhasilan MTs Unggulan Amanatul Ummah sebagai madrasah unggul dan berkualitas tinggi di mata masyarakat umum. Oleh karenanya, dari perencanaan dan pelaksanaan manajemen kepala sekolah, penelitian menunjukan adanya keberhasilan dari proses evaluasi dalam rangka meningkatkan prestasi siswa MTs Unggulan Amanatul Ummah Mojokerto.

Evaluasi sistem bimbingan wali asrama dilakukan dengan mengukur perkembangan peserta didik di asrama yang meliputi 2 aspek, yaitu: a) melakukan pengawasan dan penilaian perkembangan akhlak siswa yang dibahas dalam rapat mingguan antara ketua wali asrama bersama dengan seluruh wali asrama yang bertugas; dan b) melihat perkembangan atau peningkatanpencapaian prestasi siswa/santri dari tahun ke tahun. Tahapan evaluasi oleh wali asrama terhadap keefektifan sistem bimbingan wali asrama dalam meningkatkan prestasi siswa yang selama ini diterapkan terbukti berhasil.

\section{REFERENSI}

Abdullah, L. (2018). Kontribusi Tarekat Naqsabandiyah Terhadap Pendidikan Agama Islam Dan Perubahan Perilaku Sosial Jamaah. Nazbruna, 1(1), 1-13. http://ejournal.ikhac.ac.id/index.php/NAZHRUNA/article/view/82

Ahmadi, H. A., \& Uhbiyati, N. (1991). Ilmu pendidikan. Rineka Cipta.

Al-Qur`an. (2010). Kementerian Agama RI.

Dimyati, \& Mudjiono. (1999). Belajar dan pembelajaran. Rineka Cipta.

Fitrah, M. (2017). Peran Kepala Sekolah Dalam Meningkatkan Mutu Pendidikan. Jurnal Penjaminan Mutu, 3(1), 31-42. https://doi.org/10.25078/jpm.v3i1.90

Galela, F. (2012). Pendidikan Pola Asrama dalam Upaya Meningkatkan Mutu Pendidikan Islam di Pesantren Hidayatullah Kabupaten Fakfak [Masters, Universitas Islam Negeri Alauddin Makassar]. http://repositori.uin-alauddin.ac.id/6011/

Ghani, A. (2015). Pendidikan Akhlak Mewujudkan Masyarakat Madani. Al-Tadzkizyah: Jurnal Pendidikan Islam, 6(2), 273-284. https://doi.org/10.24042/atjpi.v6i2.1518

Hafidhuddin, D. (2003). Manajemen syariab dalam praktik. Gema Insani.

Jamal Ma mur, A. (2012). Tips Efektif Supervisi Pendidikan Sekolah. DIVA Press.

Jasmani, \& Syaiful, M. (2013). Supervisi Pendidikan. Ar-Ruz Media.

Kartiko, A., \& Kurniwan, E. (2018). Metode Bercerita Dengan Teknik Role Playing untuk Menumbuhkan Akhlak Mulia. Naz̧hruna: Jumal Pendidikan Islam, 1(2), 201-222. https://doi.org/10.31538/nzh.v1i2.52

Ma`arif, M. A., \& Rusydi, I. (2020). IMPLEMENTASI PENDIDIKAN HOLISTIK DI PONDOK PESANTREN AMANATUL UMMAH MOJOKERTO. EDUKASI: Jurnal Penelitian Pendidikan Agama Dan Keagamaan, 18(1), Article 1. https://doi.org/10.32729/edukasi.v18i1.598

Maarif, M. A., \& Rofiq, M. H. (2018). Pola Pengembangan Kurikulum Pendidikan Pesantren Berkarakter: Studi Implementasi Pendidikan Berkarakter di Pondok Pesantren Nurul Ummah Mojokerto. 13, 16.

Marzan, M. (2020). Manajemen kepala sekolah dalam meningkatkan prestasi akademik siswa SD Integral Luqman Al Hakim Surabaya [Masters, Universitas Islam Negeri Maulana Malik Ibrahim]. http://etheses.uin-malang.ac.id/17158/ 
Maulida, Y. N. (2018). Manajemen strategik dalam meningkatkan mutu pendidikan di MTs Negeri 1 Grobogan [Undergraduate, UIN Walisongo Semarang]. http://eprints.walisongo.ac.id/8828/

Miles, M. B., Huberman, A. M., \& Saldaña, J. (2014). Qualitative data analysis: A methods sourcebook (Third edition). SAGE Publications, Inc.

Muhaimin. (2012). Pengembangan Kurikulum Pendidikan Agama Islam (Cet. 5). Raja Grafindo Persada.

Perawironegoro, D. (2019). Manajemen Asrama di Pesantren. Tadbir: Jurnal Studi Manajemen Pendidikan, 3(2), 129-144. https://doi.org/10.29240/jsmp.v3i2.944

Purnomo, H., \& Umiarso, U. (2018). Pengelolaan Dan Sistem Pendidikan Islam Berwawasan Rahmatan Lil'alamin: Kajian Atas Gerakan Pendidikan Fethullah Gulen Movement. Cendekia: Jurnal Kependidikan Dan Kemasyarakatan, 16(2), 223-244. https://doi.org/10.21154/cendekia.v16i2.1288

Ramayulis. (2012). Sejarah Pendidikan Islam, Napaktilas Perubaban Konsep, Filsafat dan Metodelogi Pendidikan Islam dari Era Nabi Saw sampai Ulama`Nusantara. Kalam Mulia.

Ramayulis. (2013). Ilmu Pendidikan Islam. Kalam Mulia.

RASMI, U. S. (2019). Kepemimpinan Kepala Madrasah Dalam Mengembangkan Budaya Agama Di Madrasah Aliyah Al Hikmah Bandar Lampung [Undergraduate, UIN Raden Intan Lampung]. http://repository.radenintan.ac.id/6561/

Ridwan, M. (2018). Konsep Tarbiyah, Ta'lim Dan Ta'dib Dalam Al-Qur'an. Naz̧hruna: Jurnal Pendidikan Islam, 1(1), 35-57. https://doi.org/10.31538/nzh.v1i1.41

Rusman. (2011). Model-model pembelajaran: Mengembangkan profesionalisme guru. Rajawali Pers/PT Raja Grafindo Persada.

SARONI, M. (2006). Manajemen Sekolab: Kiat menjadi pendidik yang kompeten (Jogjakarta). Ar-Ruz Media. http://library.fip.uny.ac.id/opac/index.php?p=show_detail\&id=2759

SEIFERT, K. (2007). Manajemen Pembelajaran dan Instruksi Pendidikan: Manajemen mutu psikologi pendidikan para pendidik Jogjakarta). IRCiSoD. http://library.fip.uny.ac.id/opac/index.php?p=show_detail\&id=3172\&keywords=

Stoner, A. F., Freeman, R. E., \& Gilbert, D. R. (1996). Manajemen Edisi Bahasa Indonesia. PT. Prenballindo. Jakarta.

Susanto, E. (2007). Multikulturalisme Pendidikan Agama Islam (telaah Atas Pemikiran Nurcholish Madjid). TADRIS: Jurnal Pendidikan Islam, 2(2). http://www.ejournal.stainpamekasan.ac.id/index.php/tadris/article/view/214

Susanto, E. (2014). Pendidikan Agama Islam dalam Lanskap Post Tradisionalisme Islam. ISLAMICA: Jurnal Studi Keislaman, 6(2), 252-262. https://doi.org/10.15642/islamica.2012.6.2.252-262

SUTOPO, H. (1993). Pembinaan Dan Pengembangan Kurikulum: Sebagai Substansi Problem Administrasi Pendidikan. Bumi Aksara.

Umiarso. (2018). Kepemimpinan transformasional profetik: Kajian paradigmatik ontos integralistik di lembaga pendidikan Islam (Edisi pertama). Prenadamedia Group, Divisi Kencana.

Zainuddin, M. R. (2014). Manajemen Kepala Madrasah Dalam Pengembangan Profesionalisme Guru Pendidikan Agama Islam (pai). Edukasi: Jurnal Pendidikan Islam, 2(2), 632-644. https://doi.org/10.5281/e-journal.v2i2.166 